\title{
Impact of PUAP Programs against Rice Farmer's Income in Kupang District of East Nusa Tenggara Province
}

\section{Umbu Joka $^{\mathrm{a}}$, Lukytawati Anggraeni ${ }^{\mathrm{b}}$, Anna Fariyantic}

${ }^{a}$ Fakultas Pertanian, Universitas Timor, Kefamenanu, TTU - NTT, Indonesia.Email : umbujoka@unimor.ac.id

${ }^{b}$ Departemen Ilmu Ekonomi, Fakultas Ekonomi dan Manajemen, Institut Pertanian Bogor, Bogor -Jawa Barat, Indonesia. Email : lukytawati.anggraeni@gmail.com c Departemen Agribisnis, Fakultas Ekonomi dan Manajemen, Institut Pertanian Bogor, Bogor-Jawa Barat,, Indonesia. Email : a fariyanti@yahoo.com

\section{Article Info}

Article history:

Received 5 Desember 2018

Received in revised form 10 Desember 2018

Accepted 19 Januari 2019

DOI: https://doi.org/10.32938/ag.v4i1.624

Keywords:

Farm

Income

Impact

Rice

\section{Abstract}

Rural Agribusiness Development Program (PUAP) is a breakthrough program from Ministry of Agriculture for poverty reduction and job creation, while reducing the development gap between regions and regional centers and sub-sectors. The purpose of this study is on the impact of the PUAP program on analyze the income of rice farmers direct benefit recipients community (BLM) PUAP. The PUAP Program impact on Farmers income were analyzed using t-test, farm income analysis and linear regression model. The analysis showed PUAP program significantly affect farmer's income.

\section{Introduction}

The agricultural sector plays an important role in the Indonesian economy, especially in maintaining food security. The importance of the role of the agricultural sector is indicated by (1) the contribution to Gross Domestic Product (GDP) in 2014 amounting to 11.76 percent and ranked third larges after the manufacturing sector (21.28 percent) in the trade, hotel and restaurant sector (13.29 percent), (2) the largest absorption of labor by the agricultural sector reaches 33.9 percent, meaning that the agricultural sector has the burden of absorbing 2.75 times the ability to contribute to GDP and most of the population works in the agricultural sector and lives in rural areas (BPS 2014; Ministry of Agriculture of Indonesia Republic 2015).

The Province of East Nusa Tenggara (NTT) is one of the provinces that is lagging behind with a high poverty rate $(20.24 \%)$ and a large portion of its population (61.04 percent) earns a living as farmers while the agricultura sector share is only about half of that, which is 34.18 percent ( Ministry of Agriculture 2013). Agricultural production in NTT Province is still low where most of the land is only capable of producing for 4 (four) months in a year or only a season. This is because most farmers still focus on rice and corn (seasonal food crops) that depend on rainwater sources. BPS Data in 2014 stated that the average rice production in NTT Province is still low compared to the national production average. The average production of rice is only 32.8 $\mathrm{kW} / \mathrm{ha}$, where paddy rice is $37.15 \mathrm{~kW} / \mathrm{ha}$ and field rice is lower at $22 \mathrm{~kW} / \mathrm{ha}$ NTT Province's regional rice production reaches 477,000 tons. It is no sufficient for the rice needs of the people of NTT where with an average consumption of $124.6 \mathrm{~kg}$ / capita / year of rice it is needed as much as 585,620 tons / year, so in terms of rice production the province of NTT is classified as a deficit of 108,620 tons (NTT Agriculture Service). With a simple simulation calculation, NTT will be self-sufficient in rice if the current planting area harvest area, productivity and rice production must increase above 50 percen (de Rosary 2014). A lower increase of 50 percent has not brought NTT to the provincial level of rice self-sufficiency.

NTT Regional Government (Pemda) together with the central government through banking and non-bank institutions channel loans and capital assistance to strengthen the development of the agricultural sector (NTT 2011b Government; BPS NTT 2014). One of the regions that received allocation of funds from the PUAP Program in NTT Province was Kupang Regency. The Regency consists of 24 Sub districts, 17 Sub-Districts and 160 Villages with a land area consisting of administrative areas of villages and sub districts is $5,298.13 \mathrm{Km} 2$ with a coastline length of $442.52 \mathrm{Km}$. The sector that contributes the most to Kupang Regency GRDP is the agricultural sector because the Kupang Regency region is mostly (96.54\%) consisting of dry land and the remaining 3.46 percent is irrigated. Of the total sub-districts in Kupang Regency, the planting area reaches 21,657 ha, harvest area is 18,470 ha productivity is $33(\mathrm{kw} / \mathrm{ha}$ ) and production is $60,469.2$ tons, counted from each sub district, the largest plant area is in East Kupang District 4,619 ha, harvested area 4,619 ha, productivity $38 \mathrm{kw} /$ ha and production of tons reached 17,090.3 meaning that with the plant area in the District of East Kupang, the harvested area is also as large as the area of the plant, the largest production of all sub districts in Kupang Regency.

Even though Regionally NTT's rice productivity position is still below the national productivity, there are certain areas such as one of the regions in Kupang Regency, namely in Noelbaki Village, Kupang Tengah District as the second highest sub-district in Kupang Regency, its productivity has exceeded the National level of $4.7 \mathrm{t} / \mathrm{Ha}$. Kupang Regency also has several advantages from the technical side, namely the Office of the Agricultural Technology Assessment Agency (BPTP) in Naibonat, East Kupang District, and the Tilong Dam in Central Kupang District which irrigates 1,484 ha of agricultural land and Raknamo Dam in East Kupang District (while in development) which plan to irrigate 1,250 ha of rice fields so that it is expected that with the PUAP program accompanied by the adoption of appropriate technology will increasingly help farmers to increase productivity and income in rice farming Based on the explanation above and supported by the absence of studies related to the impact of PUAP funds in NTT Province and other provinces in Indonesia, it is necessary to study the Impact of Rural Agribusiness Business Development Program (PUAP) on the income of rice farmers in Kupang Regency. This study aims to analyze the impact of the PUAP program on the income of rice farmers receiving BLM-PUAP in Kupang Regency.

\section{Research Methods}

\subsection{Location and Time of Research}

The selection of the study sites was done by purposive sampling consideration that based on secondary data obtained, East Penfui Village, Mata Air Village, and Noelbaki Village in Middle Kupang sub-district and Oesao Village in East Kupang District were villages that had received PUAP funds and had managed and had a number of residents earn a living as the largest paddy rice farmers in Kupang Tengah District and East Kupang sub-district. To get the results of logistic regression models and multiple linear regression, 97 farmers from each farmer group were taken, consisting of 62 farmers who received PUAP funds and 35 farmers who did not receive PUAP funds. Respondents were obtained randomly, without proportions from each village in each sub-district. Data collection is carried out for two months, namely from June to July 2016

\subsection{Data Analysis}

The impact of the PUAP program on the income of wetland rice farmer was analyzed using different tests, farming analysis, and multiple linear regression models. The data used included the age of the farmer, the level of formal education, the workforce in the family, the status of land tenure, the area of land cultivated, participation outside of rice farming, the number of productive loans, and membership in farmer groups. The data was obtained through direct observation in the field and interviews for two months, namely in June to July 2016. To answer the purpose of measuring the impact of access to PUAP funds on the income of lowland rice farmers using a multiple linear regression model, to estimate the function regression of the entire population based on the existing sample regression function used the ordinary least square (OLS) method. With general forms as follows:

$$
Y_{i}=\beta_{0}+\beta_{i} X_{i}+U_{i}
$$

Where: $\mathrm{Yi}$ is the dependent variable (farming income), $\mathrm{Xi}$ is a vector of explanatory variables, $\beta \mathrm{i}$ is the estimation vector of the explanatory variable coefficients (parameters) and ui shows the disturbance variables assumed to fulfill all OLS assumptions (Gujarati 2004). In formulating a model in response to the influence of the PUAP program on farming income, the system of equations used as below refers to the results of the research by Kassa et al (2014).

\section{$\operatorname{LnFARMINC}=\beta_{0}+\beta_{1} \operatorname{LnAGE}+\beta_{2} \operatorname{LnEDUC}+\beta_{3} \operatorname{LnFAMLBR}+\beta_{4} L A N D O W N$ $+\beta_{5}$ LnLANDSZ $+\beta_{6}$ LnOFFFARM $+\beta_{7}$ KREDIT $+\beta_{8} A S S O C I$}

Where:

LnFARMINCM : Farm income (Rp)

LnAGE : Age of Farmers (Year)

LnEDUC : Duration of Formal Education (Year).

LnFAMLBR : Number of Family Members (People).

LANDOWN : Dummy land acquisition status, 1 for those who have and 0 for those who don't.

LnLANDSZ : Land area (Ha).

LnOFFFARM : Income outside of lowland rice farming (Rp).

CREDIT : Productive Loans accessed by farmers including PUAP (Rp)

ASSOCI : Farmer Group Membership Dummy, 1 for those who are joined and 0 for those who are not joined. 


\section{Result and Discussion}

\subsection{Characteristics of Respondents}

The number of respondents of rice farmers who received PUAP were 62 farmers and non-PUAP as many as 35 people. The average age of paddy farmers is still in the productive age of 48 years because the population is classified as productive age. The education taken by the respondent farmers consisted of elementary, junior high, high school, bachelor, master, but also non-school graduates. The average length of education of farmers chosen as respondents is nine years. The average number of farmer family members is four people for PUAP recipients and three for non-PUAP recipients. The farmer's arable land is an average of 0.8 ha for recipients of PUAP funds and 0.6 ha for non-PUAP is mostly arable land with a profit sharing system. According to Suratiyah (2011), the area of land affects income. The wider the arable land, the higher the income received. The average farming experience of rice farmers is 28 years for recipients of PUAP funds and 21 years for farmers who do not accept. Next can be seen in Tabel 1.

Table 1. Descriptive statistics of respondents of lowland rice farmers in Kupang Regency

\begin{tabular}{lcccc}
\hline \multirow{2}{*}{$\begin{array}{c}\text { Factors that influence the level of PTT } \\
\text { implementation }\end{array}$} & \multicolumn{2}{c}{ PUAP Recipient } & \multicolumn{2}{c}{ Non-PUAP } \\
\cline { 2 - 5 } & Average & S. Dev & Average & S. Dev \\
\hline Age & 45.69 & 9,11 & 45,97 & 10,95 \\
Formal Education & 9.67 & 3,77 & 9,34 & 3,23 \\
Farmer Experience & 26.74 & 8,61 & 19 & 11,37 \\
Dummy Membership of farmer groups & 0,98 & 0,12 & 0,77 & 0,42 \\
Dummy Participation outside of farming & 0,27 & 0,44 & 0,02 & 0,16 \\
Family labor & 4,37 & 1,48 & 3,14 & 1,71 \\
Dummy Land ownership & 0,46 & 0,50 & 0,48 & 0,50 \\
Land Size & 0,84 & 41,04 & 0,61 & 30,02 \\
Extension & 1,38 & 0,49 & 0,54 & 0,81 \\
Distance of farming location & 16,12 & 12,59 & 11,71 & 6,29 \\
Dummy planting Season & 0,79 & 0,41 & 0,45 & 0,5 \\
Productive Loans & 1000000 & 4,19 & 0 & 0 \\
\hline
\end{tabular}

\subsection{Lowland Rice Farming Income}

\section{a. The Impact of PUAP Funds on Lowland Rice Farming in Kupang Regency}

PUAP's BLM distribution is expected to also have a positive impact on the income of wetland rice farming. For this reason, before being analyzed using the Ordinary Least Square Model, farming analysis was carried out to see the comparison between costs, revenues, and farm income. In this study, farming was carried out only in one planting season. Then the results of farming calculations will be used in the analysis of the impact of PUAP credit on the income of lowland rice farming. The analysis of organic rice farming in Kupang Regency was carried out by identifying the use of inputs and outputs produced during the planting season from January to June 2016. Then analysis of costs, revenues, and farm income was carried out.

From the results of farm analysis, the $\mathrm{R} / \mathrm{C}$ ratio of farmers receiving PUAP funds was higher, which was 2.08 compared to farmers who did not receive PUAP funds worth 1.75 . This means that for farmers who receive PUAP funds and non-PUAP farmers their farming is equally profitable because everyone rupiah the costs incurred will result in revenues greater than one rupiah. But greater profits are obtained by farmers who receive PUAP assistance funds, this is due to the use of appropriate inputs and more efficient expenditure. The full results can be seen in Table 2 .

Based on the cost structure of rice paddy production (Table 2), labor is the largest cost component for farmers not recipients of PUAP funds, followed by land leasing because the average rice farming in the land is not own property with a profit sharing system. For input costs such as fertilizers and seeds, the percentage is not too large for total costs

In addition to using $\mathrm{R} / \mathrm{C}$ ratio analysis and multiple linear regression one method used to analyze the impact of the PUAP program on farm income is the real difference test. After a real difference test was obtained, respondents of lowland rice farmers who obtained PUAP BLM funds had an average income of Rp. 13,303,873, - while farmers who did not receive PUAP BLM funds received income from rice farming for an average of Rp. 6,137,464, -. To see the difference in income between PUAP recipient farmers and those who did not receive PUAP, see the Paired t-test table in the Sig. obtained $\mathrm{P}$ value $(\mathrm{P}$ value) of 0,000 smaller than the real level of 0.05 , which means rejecting $\mathrm{H} 0$, so the conclusion drawn is that there are significant differences between the two groups, namely between the recipients of PUAP funds and those who do not.

Table 2 the costs and income of paddy rice farming per hectare in Kupang District in the first planting season of 2014.

\begin{tabular}{|c|c|c|c|c|c|c|c|}
\hline & \multirow{2}{*}{$\begin{array}{c}\text { Price/ Units } \\
\text { (Rp) }\end{array}$} & \multicolumn{3}{|c|}{ PUAP recipient Farmers } & \multicolumn{3}{|c|}{ Non-PUAP Farmers } \\
\hline & & Vol & Value (Rp) & Percentage $(\%)$ & Vol. & Value (Rp) & Percentage $(\%)$ \\
\hline $\begin{array}{ll}\text { A. } & \text { Revenue (Output) }\end{array}$ & 10000 & 2152.78 & 21527850 & & 1590.6 & 15906300 & \\
\hline B. Cost & & & & & & & \\
\hline B1. Cash Fee & & & 9962458 & & & 8804040.5 & \\
\hline Seeds (Kg) & 9000 & 26.27 & 236430 & 2.54 & 25 & 241200 & 2.95 \\
\hline Organic fertilizers $(\mathrm{Kg})$ & 500 & 264.51 & 132255 & 1.28 & 97.14 & 48570 & 0.53 \\
\hline Chemical fertilizer (Kg) & & & 853876.7 & 9.33 & & 707652 & 8.74 \\
\hline Urea & 1800 & 175.8 & 473196.7 & & 160 & 291088 & \\
\hline NPK & 2300 & 205.73 & 316440 & & 126.56 & 288000 & \\
\hline TSP & 2000 & 16.12 & 32240 & & 7.14 & 14284 & \\
\hline SP36 & 2000 & 16 & 32000 & & 57.14 & 114280 & \\
\hline Outside family workforce (HOK) & & & 4705000 & 45.60 & & 4693000 & 51.72 \\
\hline Plant medicine/ pesticides (Lt) & & & 37096.7 & 0.35 & & 174538.5 & 1.92 \\
\hline Capital interest & & & 20000 & 0.19 & & & \\
\hline Land rent (land tax) & & & 3977800 & 38.55 & & 2939080 & 32.39 \\
\hline B2. No Cash Fee & & & 218500 & & & 157000 & \\
\hline Family Labor (HOK) & & 4.37 & 218500 & 2.11 & 3.14 & 157000 & 1.73 \\
\hline Total Cost $(\mathrm{B} 1+\mathrm{B} 2)$ & & & 10316739.57 & 100 & & 9073749.1 & 100 \\
\hline Income from Cash Fees (A-B1) & & & 11565392 & & & 7102259.5 & \\
\hline Revenue on Fees (A-B1-B2) & & & 11211110.43 & & & 6832550.9 & \\
\hline $\mathrm{R} / \mathrm{C}$ Cash Fee & & & 2.16 & & & 1.80 & \\
\hline $\mathrm{R} / \mathrm{C}$ Total Cost & & & 2.08 & & & 1.75 & \\
\hline
\end{tabular}

To answer the goal of measuring the impact of access to PUAP funds on the income of lowland rice farmers, using multiple linear regression models, to estimate the regression function of the entire population based on the existing sample regression function Ordinary Least Square (OLS) is used. Comprehensively, a linear regression model that uses the results equation where the variables included are factors that are thought to influence the income of rice farming, the results of parameter testing are simultaneous by showing the feasibility of the model by testing classical assumptions.

Based on table 3 the productive credit variables that are accessed have a positive effect on increasing the income of lowland rice farming. Productive credit variables are statistically significant at the 0.05 level. Even though the impact is not as big as expected, credit can increase the production of paddy rice and then increase income. In theory, with the amount of credit channeled, it will have a greater positive impact on small farming compared to large farming. Thus farmers continue to farm and access credit according to their capita capacity and farming production. This is in line with the results of Ibrahim and Bauer's study (2013) where credit has a positive impact on farm income. According to Nwaru, Onyenweaku, and Nwosu (2006), credit is an important factor in rural production activities when the main drivers of economic development are capital and technology. The importance of credit is based on the fact that credit can increase farm operational size and resource productivity. In addition, credit can facilitate technology adoption activities that can increase farm production and income resulting in capital formation.

Table 3.Factors that influence the income level of wetland rice farming in Kupang Regency in 2016

\begin{tabular}{lrr}
\hline \multicolumn{1}{c}{ Variable } & Coefficient & Sig. \\
\hline Farmers age & 0,15 & 0,19 \\
Formal education duration & $-0,03$ & 0,97 \\
Family Labor & 0,13 & 0,22 \\
Land ownership & 0,07 & 0,47 \\
Land size & $1,18^{* * *}$ & 0,00 \\
Off farm Income & $-0,10$ & 0,17 \\
Productive loans accessed & $0,05^{* * *}$ & 0,00 \\
Membership of farmer groups & $-0,07$ & 0,41 \\
Constant & 10,86 & 0.00 \\
\hline
\end{tabular}

Description: $* * *$ significant at $\alpha=1 \%$

The use of land production factors has a significant effect on the income of lowland rice farming. Positive coefficient values indicate that the level of 
production is directly proportional to the area of land where the addition of land area will increase rice production. This shows that there has been no application of innovative technology that enables increased land productivity, because the increase in rice production is achieved through the addition of land area (extensification) not through increasing the number of production per land area (intensification). The results of the study state that land-owning farmers generally cultivate larger amounts of land that are generally owned by farmers with good welfare tend to have a higher level of technology adoption. The extent of influential land related to the output productivity produced is also related to the level of trust of formal financial institutions, Hodgdon's (1966) study reports that Mudhya Pradesh Central Bank in India will not provide loans or credit assistance to farmers who are under 3 acres, supported by Desai (1971) and Gotsch (1972) who found that cooperative credit was more available to farmers with large arable land than those who worked on smallsized land.

The wider the area cultivated indicates the economy of scale, the number of inputs used, farmers who seek large land can be easier to adopt technology and efficiency in the workforce and the use of the number of inputs such as fertilizers and seeds that can be adapted to the PTT component. The duration of formal education does not affect the income of farmers, because most are at the junior secondary level. According to the research of Adwiyana et al (2016) indicates that formal education does not have a significant influence, while nonformal education has a significant level of participation at the monitoring and evaluation stage. Rice fields for productive workers who are highly educated. Membership of farmer groups is also ineffective because workers do not come from within farmer groups but laborers are hired with profit sharing systems, membership groups are only a forum for fertilizer distribution and protection assistance without having a strong impact on agricultural activities. Zahri and Febriansyah (2014) identification that business diversification has increased the participation of farmer household workers but is still indicated by a low rate of $37 \%$. The use of farmer household labor in productive economic activities occurs due to the risks and uncertainties in rice farming as a result of low water conditions that cannot be controlled, rice farming activities carried out once a year and income from rice farming do not meet the needs of farmer households, supporting why income outside of rice farming has no significant effect can even reduce the farm income coefficient.

\section{Conclusion}

From the research that has been done, it can be concluded that PUAP Fund Access has a positive impact on the income of lowland rice farmers in Kupang Regency. It is proven by the higher $\mathrm{R} / \mathrm{C}$ value of farmers who receive PUAP funds compared to farmers who do not access. Different tests also found a significant difference in the income of wetland rice between the recipient farmers and non-PUAP farmers. The factors that positively influence the income level of paddy farmers in Kupang Regency are the area of land and the amount of productive loans that are accessed.

\section{BIBLIOGRAPHY}

Adwiyana S.K, Wibowo A, Wijianto A. 2016. Hubungan Karakteristik Sosial Ekonomi Dengan Partisipasi Petani dalam Gerakan Penerapan Pengelolaan Tanaman Terpadu (GP-PTT) Kedelai di kecamatan Kedawung Kabupaten Sragen. Caraka Tani -Journal of Suistabinable Agriculture 31(2): 71-78.

[BPS] Badan Pusat Statistik Provinsi NTT 2014. Nusa Tenggara Timur dalam Angka. Kupang.

[Pemda] Pemerintah Daerah Provinsi NTT 2011b. Program Desa Mandiri Anggur Merah. Buku Panduan Pelaksanaan Program Anggur Merah. Kupang.

DeRosari B. 2014. Pengaruh Kredit dan bantuan Modal pada Perilaku Ekonomi dan Kesejahteraan Rumahtangga Tani di Provinsi Nusa Tenggara Timur Disertasi IPB.

Desai MD and BD Naik 1971. Prospects of Demand for Short-Term Institutional Credit for High-Yielding Varieties. Indian Journal of Agricultural economics. Bombay 26(4): 458-467.

Gotsch CH 1972. Technical Change and the Distribution of Income in rural Areas. American Journal of Agricultural Economics. 54(2): 326-341.

Gujarati DN. 2004. Basic Econometrics Fourth Edition. The Mc Graw HillCompanies (US): United States of America.

Hogdon LL. and H Singh 1966. Adoption of Agricultural Practices in Madhya Pradesh: Factors Associated with the Adoption of Recommended Agricultural Practices in Two Villages of Madhya Pradesh, Huderabad National Institute of Community Development, Hyderabad, India.

Ibrahim ALH and Bauer, S. 2013. Access to Micro credit and its Impact on Farm Profit Among Rural Farmers in Dryland of Sudan. Global Advanced Research Journal of Agricultural Science 2 (3): 88-102.

Kassa B, B Kassa and K Aregawi. 2014. Adoption And Impact of Agricultural Technologies On Farm Income: Evidence From Southern Tigray, Northern Ethiopia. International Journal of Food and Agricultural Economics. Vol. 2 (4): 91-106.
Kementerian Pertanian. 2015. Laporan Kinerja Direktorat Pembiayaan Pertanian Tahun 2014. Direktorat Jenderal Prasarana dan Sarana Pertanian. KEMENTERIAN PERTANIAN

Onyenweaku, C.E. and Nwaru, J.C. 2006. Application of stochastic frontier production function to the measurement of technical efficiency in food crop production in Imo State, Nigeria. The Nigerian Agricultural Journal $36: 1-2$.

Suratiyah K 2011. Ilmu Usahatani. Penebar Swadaya, Jakarta

Wati DR. 2015. Akses dan Dampak kredit Mikro terhadap Produksi dan Pendapatan Usahatani Padi Organik di Kabupaten Bogor. [Tesis]. Program Pascasarjana, Institut Pertanian Bogor, Bogor.

Zahri I dan Febriansyah A. 2014. Diversifikasi Usaha dan Pengaruhnya Terhadap Pendapatan Rumah Tangga Petani Padi Lebak. AGRISE. Vol. 14 (2):144-153. 